\title{
Three Dimensional Macroporous Calcium Phosphates Scaffolds for Bone Tissue Engineering
}

\author{
S. Teixeira ${ }^{a, b^{*}}$, M. P. Ferraz ${ }^{c}$ and F. J. Monteiro ${ }^{a, b}$ \\ ${ }^{a}$ INEB - Instituto de Engenharia Biomédica, Divisão de Biomateriais; Universidade do \\ Porto, Portugal \\ ${ }^{\mathrm{b}}$ Universidade do Porto, Faculdade de Engenharia, Departamento de Engenharia \\ Metalúrgica e Materiais, Portugal \\ ${ }^{c}$ Faculdade de Ciências da Saúde da Universidade Fernando Pessoa, Portugal \\ *s.m.dasilvateixeira@tnw.utwente.nl
}

Bone tissue engineering is a promising area that aims at developing implants capable of repairing and/ or substituting damaged or lost bone tissue. Ceramics are widely used for bone tissue engineering purposes and in this study, hydroxyapatite porous scaffolds were produced using the polymer replication method. With this method, it was possible to obtain scaffolds with specific demands adequate to tissue engineering purposes namely: macroporosity, microporosity and interconnected porosity. Polyurethane sponges were used as templates and impregnated with a ceramic slurry at different ratios being afterwards sintered following a specific thermal cycle. The characteristics of the hydroxyapatite porous scaffolds were investigated by using scanning electron microscopy and micro computer tomography ( $\mu$-CT). Human bone marrow cells (HBMC) were isolated and cultured on the scaffolds for 28 days and SEM was used as a tool to assess cell morphology and distribution.

The scaffolds were prepared using polyurethane sponges as a template and impregnated with a ceramic slurry composed by hydroxyapatite $(\mathrm{g})$, water $(\mathrm{mL})$ and surfactant (LM-3, Neodisher) as previously described. ${ }^{[1,2]}$ The $6 \mathrm{~g}(\mathrm{HA}): 4 \mathrm{~mL}\left(\mathrm{H}_{2} \mathrm{O}\right): 0.2 \mathrm{~mL}$ (tensioactive) ratio was considered as the best scaffold produced due to its adequate strength to withstand manipulation. The polyurethane sponge was squeezed to remove slurry excess and treated according to the following sintering cycle: heating at $1^{\circ} \mathrm{C} / \mathrm{min}$ followed by a $1 \mathrm{~h}$ plateau at $600^{\circ} \mathrm{C}$; heating at $4^{\circ} \mathrm{C} / \mathrm{min}$ followed by another plateau of $1 \mathrm{~h}$ at $1300^{\circ} \mathrm{C}$. Then, power was turned off and the samples were allowed to cool inside the furnace for $24 \mathrm{~h}$. The samples were then analyzed by SEM and $\mu$-CT to assess porosity. Threedimension (3D) reconstruction of scaffolds was assessed by $\mu-C T$ ( $\mu$ CT 40 - Scanco Medical) using a resolution of $10 \mu \mathrm{m}$ scans and a threshold range of 235 to 1000 . HBMCs were obtained from a donor, complying with the rules of the ethical committee, isolated and cultured on scaffolds for 28 days. After cell fixation, the samples were subjected to critical point drying, gold sputtered and observed by SEM.

The results demonstrate that the scaffolds produced are characterized by a homogeneous porous structure, with macropores ranging from 100 to $400 \mu \mathrm{m}$ and micropores from 1 to $10 \mu \mathrm{m}$. Pore interconnectivity was also present and observed by both SEM and $\mu-C T$ as demonstrated by figure 1. It was also possible to assess cell morphology and distribution by SEM during 28 days of culture in the presence of HBMC (figure 2).

It has been concluded that a 3D interconnected porous structure is desirable for tissue engineering, since the macroporosity induces osteoinduction ${ }^{[2]}$ and the microporosity allows improved cell adhesion, whereas the pore interconnectivity provides pathways for 
transport of proteins, nutrients and ultimately for tissue infiltration. Both SEM and $\mu-C T$ are suitable complementary tools to assess porosity and cell infiltration.

\section{References:}

[1] S. Teixeira, M.A. Rodriguez, P. Pena, A.H. De Aza, S. De Aza , M.P. Ferraz, F.J. Monteiro, Materials Science and Engineering C, in press.

[2] S. Teixeira, H.M. Fernandes, A. Leusink, C. van Blitterswijk, M.P. Ferraz, F.J.

Monteiro, J. de Boer,. Journal of Biomedical Materials Research, in press.
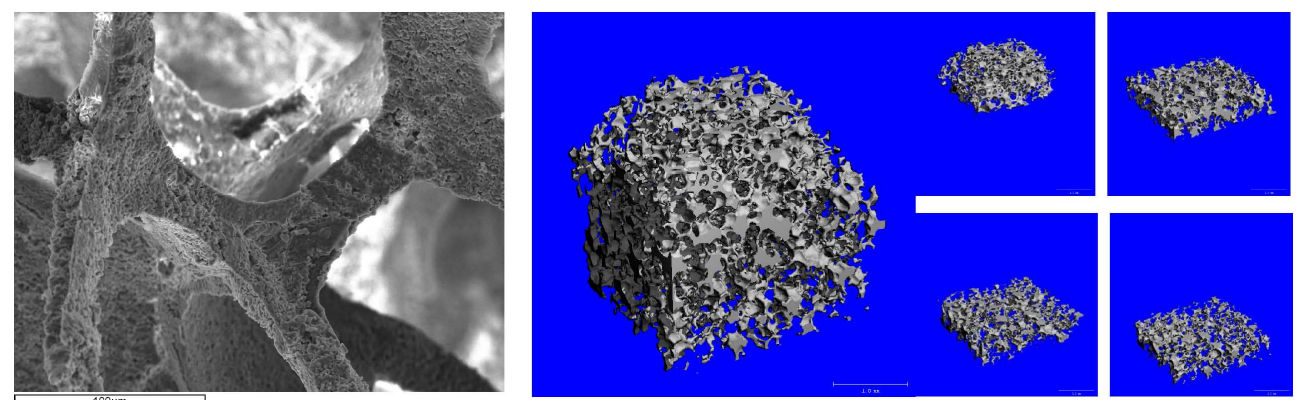

Figure 1 - Scanning electron microscopy (left) and micro computer tomography assessment (right) of the porous hydroxyapatite scaffold.
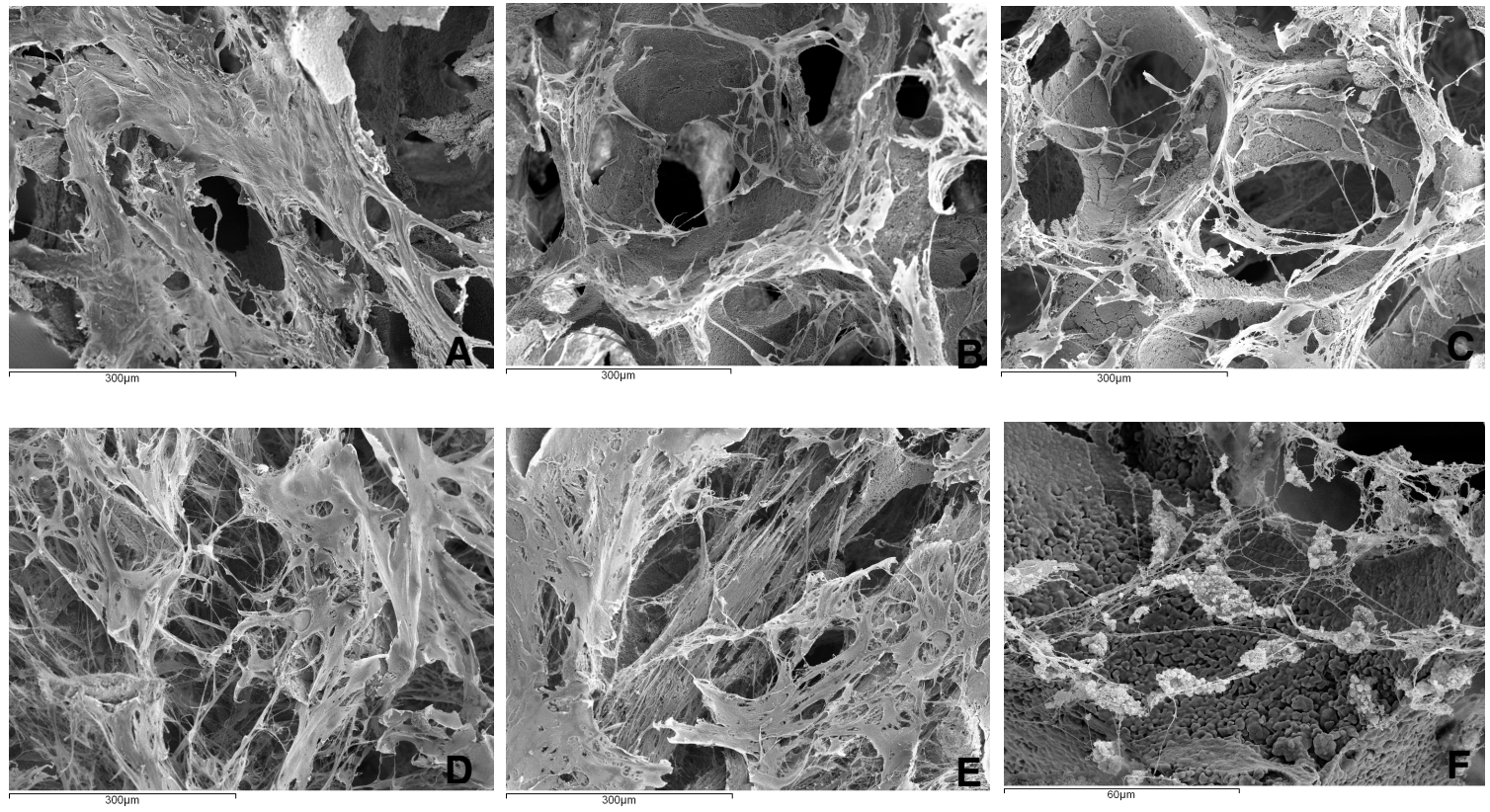

Figure 2 - HBMCs adhered to the scaffolds surface at day 1, 7, 14, 21 and 28 of cell culture, respectively (A, B, C, D and E). On day 28 (F) it was possible to visualize the presence of extracellular matrix produced by cells as confirmed by the existence of minerals. 